\title{
Acute Toxicity and Cytotoxicity Effect of Ethanolic Extract of Spondias tuberosa Arruda Bark: Hematological, Biochemical and Histopathological Evaluation
}

\author{
HUMBERTO M. BARBOSA ${ }^{1}$, JAILSON N. DO NASCIMENTO ${ }^{1}$, THIAGO A.S. ARAÚJO ${ }^{3}$, FILIPE S. \\ DUARTE ${ }^{1}$, ULYSSES P. ALBUQUERQUE ${ }^{3}$, JEYMESSON R.C. VIEIRA ${ }^{2}$, EDSON R.B. DE SANTANA ${ }^{4}$, \\ RICARDO YARA ${ }^{4}$, CLÁUDIA S.A. LIMA ${ }^{4}$, DAYANE A. GOMES ${ }^{1}$ and EDUARDO C. LIRA ${ }^{1}$ \\ ${ }^{1}$ Departamento de Fisiologia e Farmacologia, Centro de Biociências, Universidade Federal de Pernambuco, \\ Rua Prof. Moraes Rego, 1235, Cidade Universitária, 50670-901 Recife, PE, Brasil \\ ${ }^{2}$ Departamento de Histologia e Embriologia, Centro de Biociências, Universidade Federal de Pernambuco, \\ Rua Prof. Moraes Rego, 1235, Cidade Universitária, 50670-901 Recife, PE, Brasil \\ ${ }^{3}$ Laboratório de Etnobotânica Aplicada, Departamento de Biologia, Universidade Federal Rural \\ de Pernambuco, Rua Dom Manoel de Medeiros, s/n, 52171-900 Recife, PE, Brasil \\ ${ }^{4}$ Departamento de Biofísica, Centro de Biociências, Universidade Federal de Pernambuco, Rua \\ Prof. Moraes Rego, 1235, Cidade Universitária, 50670-901 Recife, PE, Brasil
}

Manuscript received on January 26, 2016; accepted for publication on May 13, 2016

\begin{abstract}
Spondias tuberosa Arruda, popularly named as umbu, is native from savanna-like vegetation and widely used for medicinal purposes, however, the toxicological profile is not available yet. This study evaluated the phytochemical profile and acute toxicity and citoxicity of Ethanolic Extract of Spondias tuberosa Arruda Bark (EEStb) in hematological, biochemical and histopathological parameters. Female Wistar rats were divided into: control $(\mathrm{C})$ and animal treated single doses of $300 \mathrm{mg} / \mathrm{Kg}\left(\mathrm{EEStb}_{300}\right)$ or $2.000 \mathrm{mg} / \mathrm{kg}$ body weight $\left(\mathrm{ESStb}_{2.000}\right)$ of the EEStb. After 24 hours and 14 days from gavage, the behavior, hematological, biochemical and histopathological parameters were assayed. Cytotoxicity effect was evaluated on HEp-2 cell lines. Neither EEStb ${ }_{300}$ nor EEStb ${ }_{2.000}$ produced mortality nor changes in body weight during the 14days of observation, but $\mathrm{EEStb}_{2.000}$ reduced quietly the food and water intake as well as locomotor activity at first day. There were no changes in macroscopic, histopathological, biochemical and hematological parameters. EEStb in concentrations of $6.25-50 \mu \mathrm{g} \mathrm{ml}^{-1}$ on HEp-2 cell did not produce cytotoxic effect. These results suggest that EEStb did not cause acute toxicity and cytotoxic, suggesting a good safety rate for Spondias tuberosa Arruda.
\end{abstract}

Key words: Acute toxicity, cytotoxicity, phytomedicine, safety, Spondias tuberosa Arruda, toxicology.

\section{INTRODUCTION}

Collectively plants produce a plethora of lowmolecular mass natural product, also known as secondary metabolites, which play a role in the

Correspondence to: Eduardo Carvalho Lira

E-mail: eduardoclira@gmail.com defense of plants against stressing conditions or pathological infections. These molecules may produce hepatotoxicity, renal failure, allergic reactions (Nortier and Vanherweghem 2007), or may cause death in humans or animals; even if ingested in small amounts. The general 
acceptability of medicinal plants has been limited by a lack of defined chemical composition, dose used, and toxicological profile to evaluate their safety (Deng et al. 2013). Unfortunately, there are few data available about toxicology for the most commonly used plants remedies.

The Anacardiaceae family of flowering plants has around 81 genera and 800 species, which are economically relevant due to agriculture and food production (Aguilar-Barajas et al. 2014). However, there are reports of poisonous species such as Toxicodendron radicans (L.) Kuntze (Tadjimukhamedov et al. 2012). Other members from Anacardiaceae show analgesic, hypoglycemic, anti-inflamatory effects in human and animal (Ojewole 2005), and antimicrobial effect in rats (Melo et al. 2014).

Seventeen species including seven taxa in the Neotropics and ten species in the Asian tropics belongs to genus Spondias L. (Miller and Schaal, 2005). Among them, Spondias tuberosa Arruda (Anacardiaceae), popularly named as umbu, is one of the most important endemic species from Brazilian semi-arid region (Lins Neto et al. 2012). It is native from savanna-like vegetation and widely for nourishment, medicinal purposes and fuel wood (Lins Neto et al. 2010). Its principal product is the fruit which acid taste is widely appreciate, however, the leaves and barks are still used in folk medicine to treatment of different diseases such as diabetes, lipids disturbance, diarrhea, inflammation, conjunctivitis, venereal diseases, menstrual colic disturbances, placental delivery, renal infection, throat afflictions and antiemetic (De Sousa Araújo et al. 2008, Lins Neto et al. 2010).

Despite the wide use of $S$. tuberosa in semiarid region from Brazil, there have been currently no reports published about their toxicological profile. This study aimed to evaluate the acute toxicity and the cytotoxicity of the ethanolic extract of $S$. tuberosa bark on behavioral, metabolic, hematological, biochemical, and histopathological parameters in rodents and cytotocixity.

\section{MATERIALS AND METHODS}

\section{PLANT MATERIAL}

Barks from 3 different trees of Spondias tuberosa were collected in February 2013 in Altinho city $\left(08^{\circ} 35^{\prime} 16.1\right.$ " S X $36^{\circ} 05^{\prime} 36.1$ " W), state of Pernambuco/Brazil and identified by Dr. Ulysses Paulino Albuquerque and a voucher specimen (\#48652) is deposited at the Herbarium of the Federal Rural University of Pernambuco (UFRPE).

\section{Preparation of Extract}

The ethanolic extract of $S$. tuberosa bark (EEStb) was prepared by maceration from dried and powdered barks (714g) in Ethanol 90\% at room temperature $\left(28^{\circ} \mathrm{C}\right)$ overnight. The solvents were removed by rotary evaporation. The yield $(\mathrm{w} / \mathrm{w})$ of the EEStb was $15.6 \%$ in terms of newly collected plant material. After preparation, the dried powder extract was stored at room temperature. The EEStb was used for preliminary phytochemical analysis and toxicological assays.

EXPERIMENTAL ANIMALS AND ETHICAL STATEMENT

Female Wistar rats $(220 \pm 10 \mathrm{~g})$ were obtained from Animal House of Physiology and Pharmacology Department at Federal University of Pernambuco. The experiment time was performed according to Organization for Economic Cooperation and Development (OECD) Guidelines 423 (2001). Rats were housed in a room with 12-12 light-dark cycle, $22^{\circ} \pm 3^{\circ} \mathrm{C}$ and were given free access to water and conventional lab chow diet(Purina, Labina ${ }^{\circledR}$, Brazil). All experiments were performed between 8:00 and 10:00 am. The protocols for these experiments were approved by the Animal Ethics Committee of the Federal University of Pernambuco (CEUA-UFPE, 
process \#: 23076.038781/2014-31) and conducted in accordance with the Ethical Principles in Animal Research.

\section{PRELIMINARY PHYTOCHEMICAL ANALYSIS}

Preliminary phytochemical analysis of the EEStb was carried by Thin Layer Chromatography (TLC) on silica gel developed by different solvent systems according to the method proposed by Wagner and Bladt (1996). It was verified the presence or absence of flavonoids, cinnamic acid derivatives, phenylpropane glycosides, condensed tannins, coumarins, alkaloids, monoterpenes, sesquiterpenes, diterpenes, triterpenes, steroids and naphthoquinones. Saponin was detected from foaming test. Foams were produced when the extract $(0.5 \mathrm{~g})$ was mixed and shaken with water $(2 \mathrm{~mL}$ ) for $30 \mathrm{~s}$ and remained for 15 minutes to confirm the presence of saponins.

\section{PHENOLIC CONTENT ASSAY}

The concentration of total phenol of EEStb was determinate by a spectrophotometric method using the Folin-Ciocalteu reagent (Singleton et al. 1999). The ethanolic extract with concentration of $1 \mathrm{mg} /$ $\mathrm{mL}$ was applied on this analysis. The reaction was prepared with $0.5 \mathrm{~mL}$ of ethanolic extract solution, where was added $2.5 \mathrm{~mL}$ of the FolinCiocalteu reagent $(10 \%)$ and $2.5 \mathrm{ml}$ of $\mathrm{NaHCO}_{3}$ (7.5\%). The samples were prepared in triplicate. Blank was prepared concomitantly, from $0.5 \mathrm{ml}$ of methanol, $2.5 \mathrm{ml}$ of Folin-Ciocalteu (10\%) and $2.5 \mathrm{ml}$ of $\mathrm{NaHCO}_{3}(7.5 \%)$. The samples were incubated on a thermostatic batch at $45^{\circ} \mathrm{C}$ for 45 min. The absorbance was measured at $765 \mathrm{~nm}(\lambda)$ for each repetition from triplicate and the media was calculated. The same procedure was repeated to gallic acid standard solution and a calibration curve was determinate. The total phenol content was expressed on terms of gallic acid equivalent (mg of GAE/g of extract).

\section{FLAVONOID CONTENT ASSAY}

The determination of flavonoids was performed according to Woisky and Salatino (1998) adapted method. EEStb $(1 \mathrm{mg} / \mathrm{mL})$, aluminum chloride hexahydrate $\left(\mathrm{AlCl}_{3} \cdot 6 \mathrm{H}_{2} \mathrm{O}\right)$ at $5 \%$ dissolved in methanol $(1 \mathrm{~mL})$ and methanol $(2 \mathrm{~mL})$ were added in test-tubes. Blank sample was prepared using $4 \mathrm{~mL}$ of methanol and $1 \mathrm{~mL}$ of $\mathrm{AlCl}_{3} \cdot 6 \mathrm{H}_{2} \mathrm{O}$. Samples remained in dark for 30 minutes and the absorbance was measured at $425 \mathrm{~nm}$. Standard solutions of quercetin in concentrations of 50, 100, 200, 300, 400 and $500 \mu \mathrm{g} / \mathrm{mL}$ were used to obtain the calibration curve. The flavonoid content was expressed in terms of quercetin equivalent ( $\mathrm{mg}$ of QUE/g of extract).

\section{CYTOTOXICITY ASSAY}

The human epidermoid cancer cells (HEp-2 cells) wereinvestigatedbytheMTTmethod[3-(4,5-dimetyl (thiazol-2-yl)-2,5 diphenyltetrazolium bromide)]. Briefly, HEp-2 cells were trypsinized, counted and prepared in a suspension with $10^{-5}$ cells $/ \mathrm{ml}$ of DMEM and distributed in a plate with 96-wells, which was incubated at $37^{\circ} \mathrm{C}$ in a humidified atmosphere for $24 \mathrm{~h}$. The EEStb was dissolved in dimethyl sulfoxide (DMSO) in concentrations of $500 \mu \mathrm{g} / \mathrm{ml}, 250 \mu \mathrm{g} / \mathrm{ml}, 125 \mu \mathrm{g} / \mathrm{ml}, 62.5 \mu \mathrm{g} / \mathrm{ml}$ and $31.2 \mu \mathrm{g} / \mathrm{ml}$ and put in the wells with the HEp-2 cells. Extracts with concentrations more than 30 $\mathrm{mg} / \mathrm{ml}$ are considered cytotoxic (Geran et al. 1972). Each concentration was tested in quadruplicate. DMEM with DMSO was used as control. After 72 h, $25 \mathrm{ml}$ of MTT and $5 \mathrm{mg} / \mathrm{ml}$ of PBS were added to the wells and the plate was incubated for $2 \mathrm{~h}$. The optical density was measured at $550 \mathrm{~nm}$ by using a microplate reader (Elx800, BioTek $^{\circledR}$, USA)

ACUTE TOXICITY EVALUATION

Acute toxicity effect of EEStb was performed in accordance with Organization for Economic Cooperation and Development (OECD) Guidelines 
423 (2001). After 5 days of acclimation in metabolic cage, nulliparous and non-pregnant female rats were fasted overnight and weighted before extract administration. The EEStb used in the assay was dissolved in distillated water and administered by gavage in rats at single dose using a animal feeding needles $(100 \mu \mathrm{L} / 100 \mathrm{~g}$ b.w.). Animals were randomly divided into 3 groups with 3 animals each: (a) control group (C) which received only distilled water, (b) $300 \mathrm{mg} / \mathrm{Kg}$ $\left(\mathrm{EEStb}_{300}\right)$ and (c) $2.000 \mathrm{mg} / \mathrm{Kg}\left(\mathrm{EEStb}_{2.000}\right)$. There is no toxicological information about Spondias tuberosa, in accordance with OECD 4003 it was evaluated 2 doses. To metabolic, hematological, biochemical and histopathological analysis were used five animals/group.

During the first 4 hours, the glycaemia and body temperature were monitored. All animals were closely observed for skin, fur, eyes, mucous membrane toxic effects and behavior patterns, lethargy, sleep, diarrhea, tremors, salivation, convulsion, coma, motor activity, and death.

\section{METABOLIC PARAMETERS}

All animals were monitored for 14 days after treatment which were kept in metabolic cage to evaluate, urinary volume, food and fluid intake daily as well as body weight gain.

\section{BIOCHEMICAL AND HEMATOLOGICAL ANALYSIS}

\section{Blood sampling}

At 24 hours and 14 days after gavage, fasting rats were anesthetized and blood was drawn from retro-orbital route with or without heparin for hematological and serum biochemical analysis, respectively.

HEMATOLOGICAL ANALYSIS

Hematological parameters included red blood cells (RBC), mean corpuscular volume (MCV), hemoglobin $(\mathrm{Hb})$, mean corpuscular hemoglobin
$(\mathrm{MCH})$, mean corpuscular hemoglobin concentration (MCHC), platelets, white blood cells (WBC), lymphocytes (LYM) and granulocytes (GRAN) were determined by an automatic hematology analyzer (SDh-20, Labtest ${ }^{\circledR}$, Brazil).

\section{SERUM BIOCHEMISTRY}

Biochemical analysis were performed for determination the following parameters: alanine (ALT) and aspartate aminotransferase (AST), alkaline phosphatase (ALP), total protein (TP), albumin (ALB), AST/ALT and albumin/globulin ratio $(\mathrm{A} / \mathrm{G})$, blood urea nitrogen $(\mathrm{BUN})$ and creatinine (CRE). Globulin was obtained from the difference between total protein and albumin.

ORGAN WEIGHT AND HISTOPATHOLOGICAL ANALYSIS

At $14^{\text {th }}$ day, all female rats were necropsied after blood collection for anatomical localization and gross examination of visible changes in the organs (aspect, color and size). Selected organs including brain, lungs, heart, liver, kidney, uterus and ovaries were carefully excised and trimmed of fat and connective tissue before being weighed. Liver and kidney were collected and their weight determined and expressed by $100 \mathrm{~g}$ of rat. The specimens of vital organs (kidney and liver) were fixed in $10 \%$ formalin buffer solution for 24 hours at room temperature and washed for 4 hour with tap water. They were then dehydrated step-wise using 70 100\% ethanol. Dehydrated tissues were turned transparent through addition of xylene. Tissues were added to pre-heated paraffin for sufficient infiltration, cooled, and made into paraffin blocks before cutting into $5 \mu \mathrm{m}$ sections using a microtome (Leica ${ }^{\circledR}$ RM 2025, Heidelberger, Germany). The paraffin was removed and specimens were dehydrated for observation with inverted optical microscope (Leica ${ }^{\circledR}$, Heidelberger, Germany) coupled to a video camera (Leica ${ }^{\circledR}$ DFC 280, Wetzlar, Germany) and a computer monitor 
after hematoxylin-eosin dyeing. The specimens of vital organs were analyzed by an experienced pathologist for any cellular damage or change in morphology and photographed. The organ weight was and expressed by $100 \mathrm{~g}$ of rats.

\section{STATISTICAL ANALYSIS}

The cytotoxicity analysis was performed by Shapiro-Wilk test using Statistical Package for the Social Sciences (SPSS) version 21 with $P$ value $<$ 0.05 . In vivo data were expressed as mean \pm S.E.M. The one-way analysis of variance (ANOVA) followed by Bonferroni test was employed to analyze the data between treated groups $\left(\mathrm{EEStb}_{300}\right.$ and $\mathrm{EEStb}_{2.000}$ ) and their respective control groups followed. $P$ value $<0.05$ was considered statistically significant.

\section{RESULTS}

PHYTOCHEMICAL ANALYSIS

Preliminary phytochemical screening of EEStb showed the presence of flavonoids, triterpen, tanins, steroid and sponins and absence of cinnamic derivates, phenylpropane glycosides, cumarins, alkaloids, naphthoquinones, monoterpenes, sesquiterpenes and diterpenes. In addition, total phenolics content varied from 20.507 to $52.747 \mathrm{mg}$ of GAE of EEStb and flavonoinds content varied from 1.457 to $10.325 \mathrm{mg}$ of QUE of EEStb (tables I and II).

\section{GenERAL METABOLIC PARAMETERS}

Neither mortality nor severe toxic or side effects were observed during all experimental period (14 days). However, behavior pattern alteration, such as reduction in locomotor activity at first day was detected at higher dose used.

There were no differences in body weight gain and total food intake between the control and EEStb treated rats in doses of 300 and $2.000 \mathrm{mg} /$ $\mathrm{Kg}$, however, the extract at the higher dose reduced quietly the food (45\%) and water (50\%) intake at $1^{\text {st }}$ day, without any alteration in urinary volume (Figure 1).

TABLE I

Results from assays to determine the total phenolic content from EEStb expressed on terms of gallic acid equivalent (mg of GAE/g of extract).

\begin{tabular}{lccc}
\hline $\begin{array}{c}\text { Extract concentration } \\
\text { Repetition }\end{array}$ & $1000 \mu \mathrm{g} / \mathrm{ml}$ & $500 \mu \mathrm{g} / \mathrm{ml}$ & $250 \mu \mathrm{g} / \mathrm{ml}$ \\
\hline A & 52.780 & 37.898 & 19.431 \\
B & 53.119 & 31.468 & 20.965 \\
C & 52.343 & 32.093 & 21.127 \\
Media & 52.747 & 33.819 & 20.507 \\
\hline
\end{tabular}

TABLE II

Results from flavonoid content from EEStb expressed on terms of quercetin equivalent (mg of QUE/g of extract).

\begin{tabular}{|c|c|c|c|}
\hline $\begin{array}{c}\text { Extract concentration } \\
\text { Repetition }\end{array}$ & $1000 \mu \mathrm{g} / \mathrm{ml}$ & $500 \mu \mathrm{g} / \mathrm{ml}$ & $250 \mu \mathrm{g} / \mathrm{ml}$ \\
\hline A & 10.752 & 4.475 & 1.525 \\
\hline B & 9.648 & 4.366 & 1.258 \\
\hline $\mathrm{C}$ & 10.576 & 4.403 & 1.590 \\
\hline Media & 10.325 & 4.414 & 1.457 \\
\hline
\end{tabular}



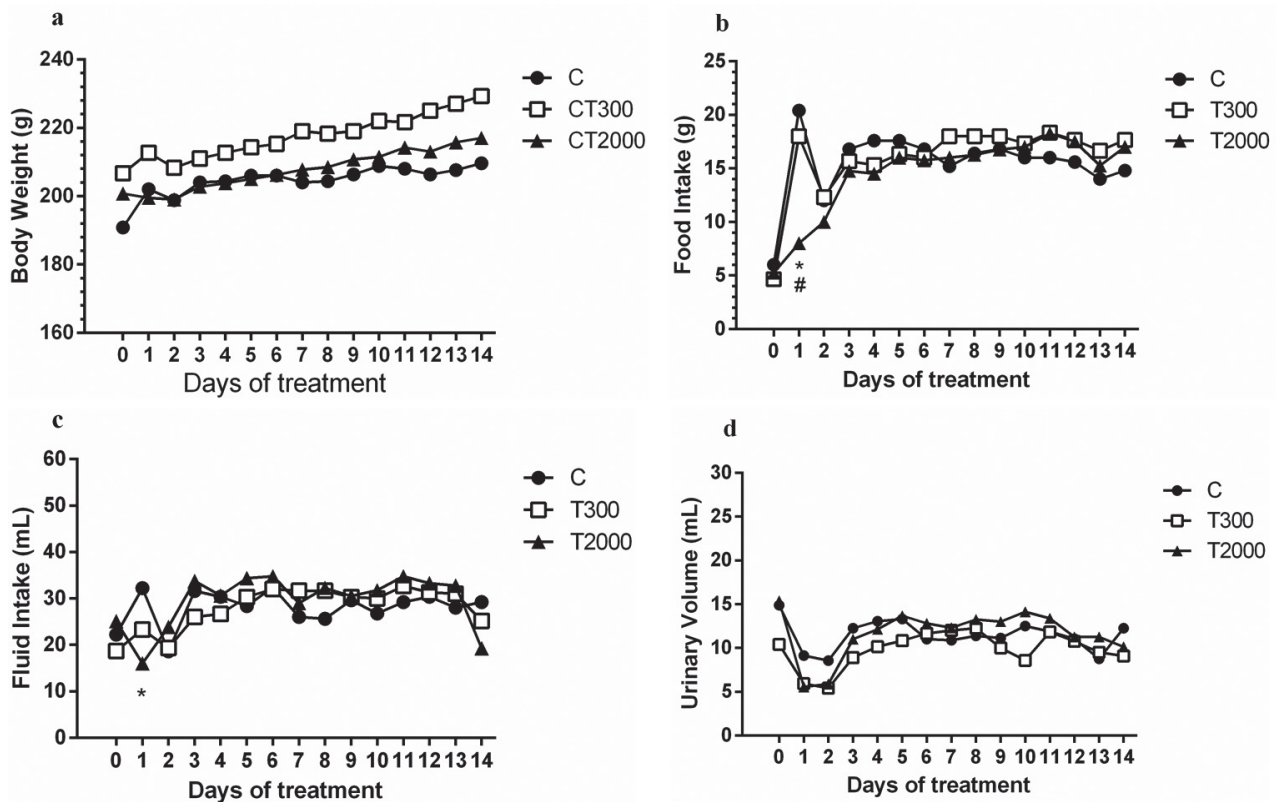

Figure 1 - Effects of acute oral treatment with the EEStb on (a) body weight; (b) food intake; (c) fluid intake and (d) urinary volume of control (C), treated with $300 \mathrm{mg} / \mathrm{kg}\left(\mathrm{EEStb}_{300}\right)$ and $2.000 \mathrm{mg} / \mathrm{kg}$ $\left(\mathrm{EEStb}_{2.000}\right)$ groups during 14 days.

\section{ORGAN WEIGHT AND HISTOPATHOGICAL ANALYSIS}

The EEStb did not show statistical significant differences on liver and kidney weights. The control $(2.9 \pm 0.1 \mathrm{mg} / 100 \mathrm{~g}$ and $0.38 \pm 0.01 \mathrm{mg} / 100 \mathrm{~g})$, $\mathrm{EEStb}_{300}(3.3 \pm 0.2 \mathrm{mg} / 100 \mathrm{~g}$ and $0.38 \pm 0.01 \mathrm{mg} / 100 \mathrm{~g})$ EEStb $_{2.000}(3.6 \pm 0.3 \mathrm{mg} / 100 \mathrm{~g}$ and $0.39 \pm 0.02$ $\mathrm{mg} / 100 \mathrm{~g})$. There were not morphological changes in liver and kidney of rats comparing with the control group. The histopathological analysis of liver and kidney after acute treatment with EEStb at both doses showed a normal kidney and liver architecture. The cords of hepatocytes $(\mathrm{CH})$ very well arranged, sinusoid capillaries (S) and central veins $(\mathrm{CV})$ without alterations (Figure 2: a, b and c). Kidney architecture with glomerulus $(\mathrm{G})$ surrounded by the Bowman's capsule (BC), Renal Tubules (RT) without any inflammatory changes when compared with the control group (Figure 2: c, $d$ and e).

\section{HEMATOLOGICAL AND SERUM BIOCHEMICAL ANALYSIS}

The serum hematological and biochemical data on $1^{\text {st }}$ and $14^{\text {th }}$ days were summarized in tables III and IV, respectively. There was no difference in the hepatic (ALT, AST, ALP, TP, ALB, GLO, ALT/ AST and A/G ratio) and renal (creatinine and urea) function among control and treated groups, as well as in any hematological index analyzed at $1^{\text {st }}$ and $14^{\text {th }}$ days.

\section{CYTOTOXICITY}

EEStb in concentrations of 31.2, 62.5, 125, 250 and $500 \mu \mathrm{g} / \mathrm{mL}$ on HEp- 2 cell lines did not produce any cytotoxic effect in cell lines when compared with control DMEM and DMSO. However, the EEStb treatment showed an increase in cell number in all concentrations mainly at $250 \mu \mathrm{g} / \mathrm{mL}$ comparing to the control group (Figure 3).

\section{DISCUSSION}

S. tuberosa Arruda is a tropical plant which plays an important role in Brazil's semi-arid region. Umbu fruit is large appreciable mainly by the taste characteristic, but also its medicinal use has been reported in the literature (Lins Neto et al. 2010, Da Silva et 


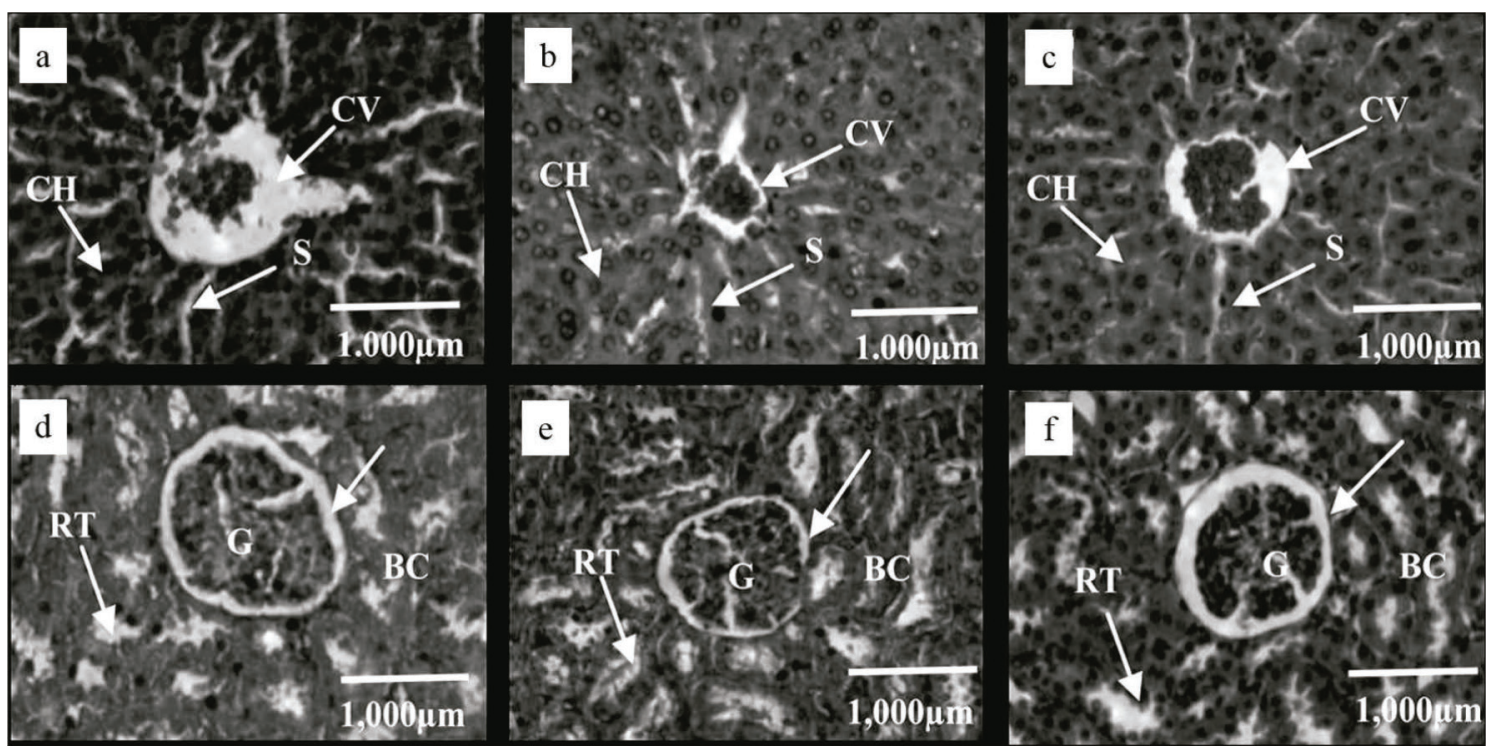

Figure 2 - Photomicrographs of hepatic tissue of rats: (a) Control group; (b) $\mathrm{EEStb}_{300}$ (c) $\mathrm{EEStb}_{2.000}$ and of renal tissue of rats: (d) Control group; (e) $\mathrm{EEStb}_{300}$ (f) $\mathrm{EEStb}_{2.000}$. Formalin fixed, HE- stained. CH - Cords of Hepatocyte; S Sinusoids capillaries; CV - Central Veins. G - Glomerulus; RT - Renal Tubules; Bowman's capsule (BC). Magnification $200 X$.

TABLE III

Effects of acute oral treatment with the EEStb on hematological parameters of control (C), treated with $300 \mathrm{mg} / \mathrm{kg}\left(\right.$ EEStb $\left._{300}\right)$ and $2.000 \mathrm{mg} / \mathrm{kg}\left(\right.$ EEStb $\left._{2.000}\right)$ groups at $1^{\text {st }}$ and $14^{\text {th }}$ day after gavage.

\begin{tabular}{lcccc}
\hline $1^{\text {st }}$ day & Unit & Control & EEStb $_{300}$ & EEStb $_{2.000}$ \\
\hline $\mathrm{RBC}$ & $10^{12} / \mathrm{L}$ & $7.5 \pm 0.2$ & $7.0 \pm 0.2$ & $6.5 \pm 0.8$ \\
$\mathrm{MCV}$ & $\mathrm{Fl}$ & $56.4 \pm 0.8$ & $54.2 \pm 0.3$ & $55.2 \pm 0.6$ \\
$\mathrm{Hg}$ & $\mathrm{g} / \mathrm{dL}$ & $15.4 \pm 0.4$ & $14.4 \pm 0.3$ & $15.0 \pm 0.6$ \\
$\mathrm{MCH}$ & $\mathrm{pg}$ & $20.5 \pm 0.2$ & $21.0 \pm 0.2$ & $20.6 \pm 0.1$ \\
$\mathrm{MCHC}$ & $\mathrm{g} / \mathrm{dL}$ & $36.4 \pm 0.3$ & $37.8 \pm 0.3$ & $37.8 \pm 0.3$ \\
$\mathrm{HCT}$ & $\%$ & $42.3 \pm 1.1$ & $38.1 \pm 0.9$ & $40.0 \pm 1.6$ \\
$\mathrm{WBC}$ & $10^{9} / \mathrm{L}$ & $6.3 \pm 0.4$ & $7.2 \pm 0.6$ & $6.8 \pm 0.6$ \\
$\mathrm{LYM}$ & $10^{9} / \mathrm{L}$ & $5.7 \pm 0.2$ & $6.7 \pm 0.5$ & $6.4 \pm 0.8$ \\
$14^{\text {th }}$ day & & & & \\
$\mathrm{RBC}$ & $10^{12} / \mathrm{L}$ & $7.5 \pm 0.3$ & $7.5 \pm 0.3$ & $7.7 \pm 0.1$ \\
$\mathrm{MCV}$ & $\mathrm{Fl}$ & $57.0 \pm 1.0$ & $55.7 \pm 0.4$ & $56.8 \pm 0.4$ \\
$\mathrm{Hg}$ & $\mathrm{g} / \mathrm{dL}$ & $15.7 \pm 0.5$ & $15.9 \pm 0.6$ & $15.8 \pm 0.2$ \\
$\mathrm{MCH}$ & $\mathrm{pg}$ & $21.0 \pm 0.2$ & $20.4 \pm 0.2$ & $20.6 \pm 0.1$ \\
$\mathrm{MCHC}$ & $\mathrm{g} / \mathrm{dL}$ & $36.9 \pm 0.7$ & $36.4 \pm 0.3$ & $36.2 \pm 0.2$ \\
$\mathrm{HCT}$ & $\%$ & $42.6 \pm 1.7$ & $43.7 \pm 2.0$ & $43.7 \pm 0.6$ \\
$\mathrm{WBC}$ & $10^{9} / \mathrm{L}$ & $4.5 \pm 0.3$ & $5.4 \pm 0.9$ & $5.5 \pm 0.8$ \\
$\mathrm{LYM}$ & $10^{9} / \mathrm{L}$ & $4.2 \pm 0.3$ & $4.9 \pm 0.8$ & $4.4 \pm 0.4$ \\
\hline
\end{tabular}


TABLE IV

Effects of acute oral treatment with the EEStb on biochemical parameters of control $(\mathrm{C})$, treated with $300 \mathrm{mg} / \mathrm{kg}\left(\operatorname{EEStb}_{300}\right)$ and $2.000 \mathrm{mg} / \mathrm{kg}\left(\operatorname{EEStb}_{2.000}\right)$ groups at $1^{\text {st }}$ and $14^{\text {th }}$ day after gavage.

\begin{tabular}{lcccc}
\hline $1^{\text {st }}$ day & $\mathrm{Unit}$ & Control & $\mathrm{EEStb}_{300}$ & $\mathrm{EEStb}_{2.000}$ \\
\hline AST & $\mathrm{U} / \mathrm{L}$ & $148.2 \pm 9.3$ & $129.08 \pm 8.21$ & $111.24 \pm 7.52$ \\
ALT & $\mathrm{U} / \mathrm{L}$ & $46.8 \pm 2.8$ & $63.6 \pm 6.7$ & $54.9 \pm 7.7$ \\
AST/ALT ratio & $\mathrm{U} / \mathrm{L}$ & $2.8 \pm 0.2$ & $2.2 \pm 0.1$ & $2.2 \pm 0.1$ \\
ALP & $\mathrm{U} / \mathrm{L}$ & $40.32 \pm 6.67$ & $48.61 \pm 8.76$ & $35.38 \pm 8.52$ \\
Albumin & $\mathrm{g} / \mathrm{dL}$ & $2.74 \pm 0.13$ & $2.54 \pm 0.9$ & $2.93 \pm 0.9$ \\
Total protein & $\mathrm{g} / \mathrm{dL}$ & $5.97 \pm 0.28$ & $6.74 \pm 0.19$ & $5.73 \pm 0.36$ \\
Globulin & $\mathrm{g} / \mathrm{dL}$ & $3.22 \pm 0.36$ & $4.25 \pm 0.22$ & $2.81 \pm 0.46$ \\
A/G ratio & $\mathrm{g} / \mathrm{dL}$ & $0.90 \pm 0.11$ & $0.64 \pm 0.06$ & $1.01 \pm 0.17$ \\
Urea & $\mathrm{mg} / \mathrm{dL}$ & $44.81 \pm 7.80$ & $35.52 \pm 1.25$ & $33.61 \pm 2.15$ \\
Creatinine & $\mathrm{mg} / \mathrm{dL}$ & $0.28 \pm 0.03$ & $0.29 \pm 0.5$ & $0.31 \pm 0.05$ \\
$14^{\text {th }}$ day & & & & \\
AST & $\mathrm{U} / \mathrm{L}$ & $138.68 \pm 6.38$ & $116.27 \pm 12.30$ & $129.21 \pm 9.45$ \\
ALT & $\mathrm{U} / \mathrm{L}$ & $48.9 \pm 4.55$ & $43.7 \pm 11.2$ & $45.4 \pm 6.7$ \\
ALT/AST ratio & $\mathrm{U} / \mathrm{L}$ & $2.7 \pm 0.3$ & $2.5 \pm 0.3$ & $3.0 \pm 0.3$ \\
ALP & $\mathrm{U} / \mathrm{L}$ & $29.71 \pm 3.19$ & $26.40 \pm 2.74$ & $42.96 \pm 7.91$ \\
Albumin & $\mathrm{g} / \mathrm{dL}$ & $2.60 \pm 0.08$ & $2.44 \pm 0.18$ & $2.61 \pm 0.13$ \\
Total protein & $\mathrm{g} / \mathrm{dL}$ & $6.29 \pm 0.20$ & $6.56 \pm 0.19$ & $6.33 \pm 0.20$ \\
Globulin & $\mathrm{g} / \mathrm{dL}$ & $3.69 \pm 0.23$ & $4.12 \pm 0.23$ & $3.71 \pm 0.12$ \\
A/G ratio & $\mathrm{g} / \mathrm{dL}$ & $0.73 \pm 0.06$ & $0.65 \pm 0.07$ & $0.71 \pm 0.03$ \\
Urea & $\mathrm{mg} / \mathrm{dL}$ & $47.16 \pm 3.30$ & $46.28 \pm 2.83$ & $42.32 \pm 2.48$ \\
Creatinine & $\mathrm{mg} / \mathrm{dL}$ & $0.42 \pm 0.06$ & $0.47 \pm 0.01$ & $0.49 \pm 0.03$ \\
\hline & & &
\end{tabular}

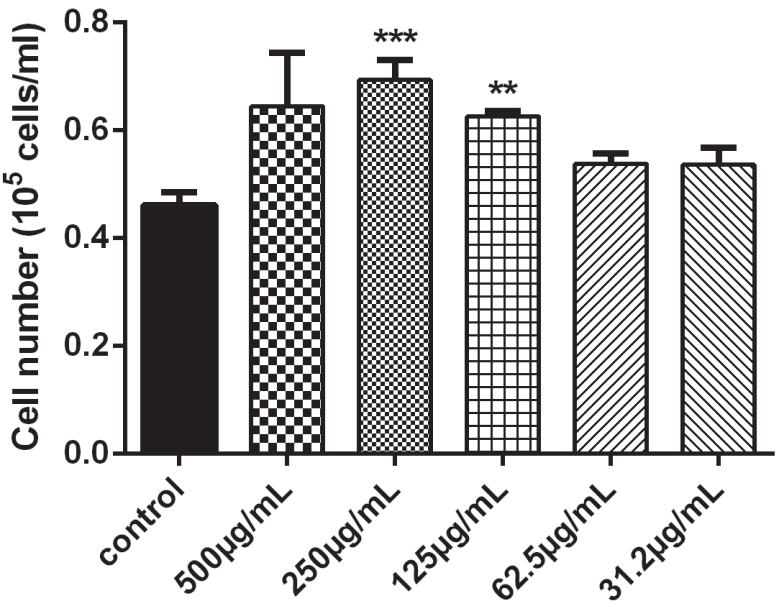

Figure 3 - Effects of EEStb on HEp-2 Cell number *** $\mathrm{p}<0.001$ and $* * \mathrm{p}<0.01$ vs control $216 \times 161 \mathrm{~mm}$.

al. 2012). The importance of S. tuberosa in folk medicine, human nutrition and its pharmacological potential makes this toxicological evaluation on it imperative. In literature, there is no information about safety of $S$. tuberosa on medicinal propose. Here these results demonstrated that EEStb showed toxicity effects neither in vivo nor in vitro.

In this study, the preliminary phytochemical screening of EEStb showed the presence of flavonoids, triterpen, tanins, steroid and sponins and absence of cinnamic derivates, phenylpropane glycosides, cumarins, alkaloids, naphthoquinones, monoterpenes, sesquiterpenes and diterpenes. In addition, total phenolics content varied from 20.507 to $52.747 \mathrm{mg}$ of GAE of EEStb and flavonoids content varied from 1.457 to $10.325 \mathrm{mg}$ of QUE of EEStb as soon in tables I and II, respectively. Reports have shown hydrolysable tannis, flavones, flavonoids, and phenols in extracts of leaves and fruits of Spondias tuberosa (De Sousa Araújo et al. 2012, Da Silva et al. 2012, Zielinski et al. 2014). In addition, Da Silva et al. (2012) detected by diode array detectors (HPLC-PDA) rutin, 
ellagic acid and quercetin. Here, we confirmed the presence of total phenolics and flavonoids through spectrophotometric methods. Previous studies have shown the occurrence of those phytochemicals in fruits and leaves of S. tuberosa (Zielinski et al. 2014, Da Silva et al. 2012), but until our acknowledgment this is the first report in bark.

Analyses of several physiological parameters such as behavior, body weight, food intake, biochemical, hematological and histological analysis are used to evaluate toxicity in animals and humans (Ahmad et al. 2013). Neither mortality nor severe toxic or clinical signs were observed during all experimental period. There were no differences in body weight gain and total food intake between the control and EEStb ${ }_{300}$ and EEStb ${ }_{2.000}$ groups (Figure 1). However, the extract at the higher dose reduced the food (45\%) and water $(50 \%)$ intake at $1^{\text {st }}$ day, without any alteration in urinary volume intake (Figure 1). At first day, reduction in locomotor activity was induced by $\mathrm{EEStb}_{2.000}$. Notwithstanding, there were no difference among the groups on clinical signs patterns, such as salivation and diarrhea.

Considering that flavonoid has been shown to exert effects on CNS, meanly both sedative and analgesics (Fernández et al. 2006), it can be speculated that the transient reduction in food and water intake could be associated to the flavonoids content in EEStb and their effects on CNS. It is well known that gamma aminobutyric acid (GABA), the major inhibitory neurotransmitter in the CNS, is vital for the overall balance between neuronal inhibition and excitation through its interaction with specific heteromeric GABA-gated chloride channels receptor. Many studies have been correlated to the affinities of diverse natural and synthetic flavonoids for the benzodiazepine binding sites located to the GABA receptors to their pharmacological effects in vivo such as anticonvulsant, sedative or anxiolytic effect (Viola et al. 1995, Griebel, et al. 1999, Gouteman et al.
2003, Jäger and Saaby, 2011). Flavonoids, such as apigenin, quercetin and chrysin, are sedative in rodents (Gouteman et al. 2003, Jäger and Saaby 2011) and its probably occurrence in EEStb could, at least in part, explain the reduction in food and water intake and locomotor activity observed at first day in $\mathrm{EEStb}_{2.000}$ group. Other experiments must be undertaken to clarify this mechanism.

The hematopoietic system is one the most sensitive target for toxic molecules (Olson et al. 2000). Among important clinical alterations, the haematological parameters provide a reliable index to evaluate health and pathological conditions in human and animal (Gautam and Goel 2014). In this report, both red and white blood cells profile was analyzed as important toxicological index. Our results showed that EEStb neither provoked anemia nor immune system stimulation (table III). Here, we did not observe any haematological toxicity effect and did not interfere or cause any injury to the circulating red and white blood cells or platelets, corroborating the wide safety margin of the EEStb. In addition, EEStb neither modified serum glucose levels nor body temperature (data not shown), supporting that EEStb have no toxic effect acutely.

Macroscopical analysis revealed that the EEStb $_{300}$ and EEStb ${ }_{2.000}$ did not cause any effect on organ weight such as kidney and liver. Once that, those organs represent the most sensitive to show toxicity when they are exposed to potential harmful compounds (Olson et al. 2000, Luka et al. 2014), histopathological analysis of both were performed. Acute treatment with EEStb at both doses showed a normal liver architecture with cords of hepatocytes $(\mathrm{CH})$ very well arranged, sinusoid capillaries (S) and central veins $(\mathrm{CV})$ without alterations as well as normal kidney architecture with glomerulus (G) surrounded by the Bowman's capsule (BC). $\mathrm{EEStb}_{2.000}$ group showed a minor change in pericapsular space suggesting alteration in glomeruli (Figure 2f). Those changes should be confirmed 
by histomorfometric analysis. Renal Tubules (RT) without any inflammatory changes when compared with the control (Figure 2).

It is well established that serum enzymes alanine (ALT) and aspartate (AST) transferase are sensitive biomarkers to evaluate hepatotoxicity. Here, hepatic function has been monitored by the evaluation of the serum level of ALT, AST and phosphatase alkaline (ALP). Hepatocellular necrosis leads to high levels of ALT and AST, which are released from liver into the blood. ALP activity, on the other hand, is related to the functioning of hepatocytes (Pan et al. 2009). In the present study, there were no significant changes in hepatic enzymes, suggesting that the EEStb did not cause any damage to the hepatic functions. Further, no impairment was detected in kidney function marks such as increasing in creatinine and urea levels (table IV).

Albumin and globulin are the most important plasmatic proteins and they represent a good criterion for assessing synthetic liver capacity (Pan et al. 2009). In addition, hepatocellular damage leads a reduction in albumin accompanied by a relative increase in globulins, which decrease $\mathrm{A} / \mathrm{G}$ ratio (Santhosh et al. 2007). In hepatotoxic conditions, a significant reduction in serum urea was detected due the failure of the liver in converting amino acids and ammonia into urea (Reichen and Paumgartner 1980). In this study, EEStb did not change albumin, globulin and urea levels at first and $14^{\text {th }}$ days of experiment (table IV). Considering that histopathological analysis and microscopy examination did not reveal any insult in liver or kidney histomorphology (Figure 2), our results suggest that the EEStb did not show nephrotoxic and hepatotoxic effects.

It could be speculated that $\mathrm{LD}_{50}$ of EEStb is found to be more than $2.000 \mathrm{mg} / \mathrm{Kg}$ (OECD 2001). Substances with $\mathrm{LD}_{50}$ higher than $1.000 \mathrm{mg} / \mathrm{Kg}$ by oral route are regarded as being safe or slightly toxic (Garner 1975) and this study shows that EEStb produce little or no short-term effects on rats. The results suggest that EEStb is safety to the popular use and it makes the species interesting for future pharmacological investigation.

To confirm the safety in vivo use of the EEStb, we evaluated the cytotoxity in HEp-2 cells. This extract did not cause cytotoxicity in any concentrations. On the other hand, EEStb was able to stimulate the HEp-2 proliferation, with a higher effect at $250 \mu \mathrm{g} / \mathrm{mL}$ (Figure 3), suggesting a possible mitogenic mechanism of the extract in HEp-2 cells. Further studies on the mechanism of action of EEStb and its effects on cell lines under laboratory conditions are in progress.

\section{CONCLUSIONS}

This study is the first reports in literature that provide preliminary in vitro and in vivo evidences about the Spondias tuberosa safety. The data show that EEStb did not cause any death or acute toxicity signs, as well as also showed mitogenic effect, suggesting the EEBSt as a promise to future biological investigation. The species is widely used for traditional communities in Brazil Northeast for different purposes; including treatment of several diseases and this study constitute safety information to human and animal use as well as future pharmacological studies to guarantee the safety of this plant species when used as a phytomedicine. The phytochemical profile associated to absence of toxic effects highlights the EEStb promise to future pharmacological investigations.

\section{RESUMO}

Spondias tuberosa Arruda, popularmente conhecida como umbu, é uma espécie nativa da Caatinga amplamente utilizada na medicina popular, cujo perfil toxicológico ainda não é conhecido. Deste modo, este estudo avaliou o perfil fitoquímico, a toxicidade aguda e a citotoxicidade do extrato etanólico da casca da Spondias tuberosa Arruda (EEStb) nos parâmetros hematológicos, bioquímicos e histopatológicos. Foram utilizados ratos fêmeas Wistar $( \pm 210 \mathrm{~g})$ e divididos em: grupo controle 
(C) e tratados com uma dose única de $300 \mathrm{mg} / \mathrm{Kg}$ (EES$\mathrm{tb}_{300}$ ) ou $2.000 \mathrm{mg} / \mathrm{kg}$ do peso corporal $\left(\mathrm{ESStb}_{2.000}\right)$ do EEStb. Após 24 horas e 14 dias da gavagem, os parâmetros comportamentais, hematológicos, bioquímicos e histopatológicos foram determinados. O efeito citotóxico foi avaliado em células HEp-2. Não foi observada mortalidade ou alterações de massa corporal durante os 14 dias de experimento nos grupos EEStb $_{300}$ e EES$\mathrm{tb}_{2.000}$, mas EEStb ${ }_{2.000}$ provocou uma redução discreta no consumo hídrico e alimentar, assim como na atividade locomotora no $1^{\circ}$ dia de tratamento. Não houve alterações nos parâmetros histopatológicos, macroscópicos, bioquímicos e hematológicos. $\mathrm{EEStb}_{2000}$ nas concentrações de $6.25-50 \mu \mathrm{g} \cdot \mathrm{ml}^{-1}$ ) não produziu efeito citotóxico. na célula HEp-2. Estes resultados sugerem que EEStb não promoveu toxicidade aguda ou citotóxica, sugerindo boa margem de segurança para uso da Spondias tuberosa Arruda.

Palavras-chave: Toxicidade aguda, citotoxicidade, fitomedicina, segurança, Spondias arruda, toxicologia.

\section{ACKNOWLEDGMENTS}

This work received financial support from Conselho Nacional de Desenvolvimento Científico e Tecnológico (CNPq) (Research fellowships) and Propesq/UFPE.

\section{REFERENCES}

Aguilar-Barajas E, SORK VL, GONZÁlez-ZAMORA A, RoChA-RAMIREZ V, ARroyo-RodrigueZ V AND OYAMA K. 2014. Isolation and characterization of polymorphic microsatellite loci in Spondias radlkoferi (Anacardiaceae). Appl Plant Sci 3: 1-3.

AHMAD M, LIM CP, AKOWUAH GA, ISMAIL NN, HASHIM MA, HOR SY, ANG LF AND YAM MF. 2013. Safety assessment of standardised methanol extract of Cinnamomum burmannii. Phytomedicine 15: 1124-1130.

Da Silva AR, De Morais SM, Marques MM, De OLIVERIA DF, BARROS CC, DE ALMEIDA RR, VIEIRA IG AND GUEDES MI. 2012. Chemical composition, antioxidant and antibacterial activities of two Spondias species from Northeastern Brazil. Pharm Biol 50: 740-746.

DE SOUSA ARAÚJo TA, ALENCAR NL, DE AMORIM EL AND DE ALBUQUeRQUe UP. 2008. A new approach to study medicinal plants with tannins and flavonoids contents from the local knowledge. J Ethnopharmaco 120: $72-80$.
De Sousa Araújo TA, De Almeida e CAstro VT, DE AMorim EL AND AlbuQUerque UP. 2012. Habitat influence on antioxidant activity and tannin concentrations of Spondias tuberosa. Pharma Biol 50: 754-759.

DENG YX ET AL. 2013. Toxicological evaluation of neem (Azadirachta indica) oil: acute and subacute toxicity. Environ Toxicol Pharmacol 35: 240-246.

FERNÁNDEZ SP, WASOWSKI C, LOSCALZO LM, GRANGER RE, Johnston GA, PALAdini AC AND MARder M. 2006. Central nervous system depressant action of flavonoid glycosides. Eur J Pharmacol 539: 168-176.

GARNER RJ. 1975. Veterinary Toxicology. London: Cassel and Collier Macmillan Publishers, 438 p.

GAUTAM MK AND GOEL RK. 2014. Toxicological Study of Ocimum sanctum Linn Leaves: Hematological, Biochemical, and Histopathological Studies. J Toxicol, p. 1-9.

Geran Ri, Greenberg NH, Macdonald MM, SCHUMACHER AM AND ABBOTT BJ. 1972. Protocols for screening chemical agents and natural products against animal and other biological systems. Cancer Chemother Rep 3: 17-19.

Goutman JD, WAXEMBERG MD, DONATE-Oliver F, POMATA PE AND CALVO DJ. 2003. Flavonoid modulation of ionic currents mediated by $\operatorname{GABA}(\mathrm{A})$ and $\operatorname{GABA}(\mathrm{C})$ receptors. Eur J Pharmacol 461: 79-87.

Griebel G, Perrault G, TAN S, Schoemaker H AND SANGER DJ. 1999. Pharmacological studies on synthetic flavonoids: comparison with diazepam. Neuropharmacology 38: 965-977.

JÄGER AK AND SAABY L. 2011. Flavonoids and the CNS. Molecules 16: 1471-1485.

Lins Neto EM, Peroni N And De Albuquerque UP. 2010. Traditional Knowledge and Management of Umbu (Spondias tuberosa, Anacardiaceae): An Endemic Species from the Semi-Arid Region of Northeastern Brazil. Econ Bot 64: 11-21.

Lins Neto EM, PERoni N, MARANHÃo CM, MACIEL MI AND DE AlBUQUeRQUe UP. 2012. Analysis of umbu (Spondias tuberosa Arruda (Anacardiaceae) in different landscape management regimes: a process of incipient domestication? Environ Monit Assessm 184: 4489-4499.

LUKA J, BADAU SJ, MBAYA AW, GADZAMA JJ AND KUMSHE HA. 2014. Acute toxicity study and effect of prolonged administration (28 days) of crude ethanolic root extract of Diospyros mespiliformis (Ebenaceae) on clinical, haematological and biochemical parameters of albino rats. J Ethnopharmacol 15: 268-273.

Melo MC, GADELHA DN, OLIVEIRA TK AND BRANDT CT. 2014. Alcohol extract of Schinu sterebinthifolius raddi (anacardiaceae) as a local antimicrobial agent in severe autogenously fecal peritonitis in rats. Acta Cir Bras 29: $52-56$. 
Miller A AND SCHAAL B. 2005. Domestication of a Mesoamerican cultivated fruit tree, Spondias purpurea. Proc Natl Acad Sci USA 102: 12801-12806.

NORTIER JL AND VANHERWEGHEM JL. 2007. For patients taking herbal therapy - lessons from aristolochic acid nephropathy. Nephrol Dial Transplant 22: 1512-1517.

OECD. 2001. "Acute Oral Toxicity: Acute Toxic Class Method." Test Guideline 423, 2001.

OJEWOLE JA. 2005. Anti-inflamatory, analgesic and hypoglycemic effects of Magnifera indica Linn (Anacardiaceae) stem-bark aqueous extract. Methods Find Exp Clin Pharmacol 27: 547-554.

OLSON H ET AL. 2000. Concordance of the toxicity of pharmaceuticals in humans and in animals. Regul Toxicol Pharmacol 32: 56-57.

PAN X, Chang F, LiU Y, Xu A, Shen Y AND HuAng Z. 2009. Mouse toxicity of Anabaena flos-aquae from Lake Dianchi, China. Environ Toxicol 24: 10-18.

REICHEN J AND PAUMGARTNER G. 1980. Excretory function of the liver. Int Rev Physiol 21: 103-150.

SANTHOSH S, Sini TK, ANANDAN R AND MATHEW PT. 2007. Hepatoprotetive activity of chitosan against isoniazid and fifampicin-induced toxicity in experimental rats. Eur J Pharmacol 15: 69-73.
SINGLETON VL, ORTHOFER R AND LAMUELA-RAVENTÓS RM. 1999. Analysis of total phenols and other oxidation substrates and antioxidants by means of Folin-Ciocalteu reagent. Methods Enzymol 299: 152-178.

TADJIMUKHAMEDOV FK, HUANG G, OUYANG Z AND COOKS RG. 2012. Rapid detection of urushiol allergens of Toxicodendron genus using leaf spray mass spectrometry. Analyst 137: 1082-1084.

VIOLA H, WASOWSKI C, LEVI DE STEIN M, WOLFMAN C, Silveira R, DAJAS F, MEdina JH AND PALAdini AC. 1995. Apigenin, a component of Matricaria recutita flowers, is a central benzodiazepine receptors-ligand with anxiolytic effects. Planta Med 61: 213-216.

Wagner H AND BladT S. 1996. Plant Drug Analysis: A Thin Layer Chromatography Atlas, $2^{\text {nd }}$ ed., Hedelberg, Germany: Springer-Verlag, $384 \mathrm{p}$.

WOISKY RG AND SALATINO A. 1998. Analysis of propolis: some parameters and procedure for chemical quality control. J Apicultural Research 37: 99-105.

ZiElinski AA, Ávila S, ITO V, NogUeira A, Wosiacki G AND HAMINIUK CW. 2014. The association between chromaticity, phenolics, carotenoids, and in vitro antioxidant activity of frozen fruit pulp in Brazil: an application of chemometrics. J Food Sci 79: 510-516. 